\title{
APPLICATION OF WCIA-C:H COATING IN HYDRAULIC MOTORS
}

\author{
Andrzej KUBIK, Henryk BĄKOWSKI, Zbigniew STANIK \\ Silesian University of Technology, Gliwice, Poland, EU, \\ andrzej.kubik@polsl.pl, henryk.bakowski@polsl.pl, zbigniew.stanik@polsl.pl
}

https://doi.org/10.37904/metal.2019.896

\begin{abstract}
The article presents an analysis of the consumption of low-carbon steel and DLC coating working in a sliding combination with rotational motion and in various operating conditions. The influence of selected operational factors, i.e. the speed and load on wear and the coefficient of friction in sliding combination, as well as their graphical interpretation of test results based on the results obtained from experimental and metallographic investigations are shown. Tests carried out at the tribological stand T01M operating in the stem-disc system were preliminary tests. Initial tests allowed to determine the influence of the determined operating parameters on selected tribological properties. Low-carbon steel, designed for thermo-chemical treatment and DLC coating, was used for the tests. Metallographic examinations allowed to determine the dominant mechanism of wear, depending on external factors.
\end{abstract}

Keywords: DLC coating, tribology, wear, hydraulic motors

\section{INTRODUCTION}

A thorough analysis of the friction and wear processes of individual components and subassemblies is one of the basic tasks that must be taken into account in the construction and operation of machines. This knowledge is needed to improve the operational properties of individual components, resulting in longer machine life and, for example, process lines. Destruction of the surface layer is referred to as wear. The wear process, on the other hand, is called the continuous process of changes in the surface of co-operating surfaces and the change in mass, structure and stresses occurring in the surface layers of materials. Changes in the surface

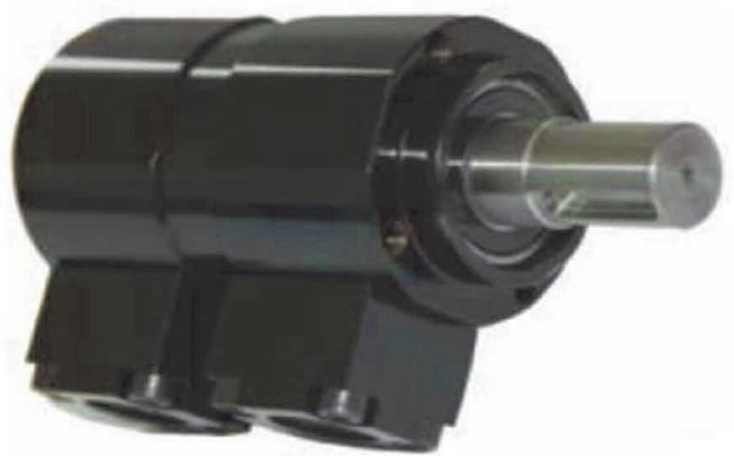

Figure 1 Low power hydraulic motor [4] condition of the material depend on the increase of the roughness value and its damage [1-3]. The subject of study in the article are low power hydraulic motors. Figure 1 shows one of the tested hydraulic motors.

Hydraulic motors are an executive function in the drive system. Their task is to change the energy of the working fluid pressure into mechanical energy.

The durability of the hydraulic motor depends to a large extent on the operation of the satellite mechanism and the compensating disc. Consumption of these elements should be small. In the operation of these motors there is a problem of excessive wear of components cooperating with each other, i.e. a satellite and a compensation plate. Excessive wear of one or the other element causes leaks and excessive pressure drops, which reduces the efficiency and ultimately results in the immobilisation of the hydraulic motor [5].

The results tribological test the satellite mechanism and a compensating disc allow to state the validity of the application layer of WC / a-C: H. 


\section{DLC COATING}

The necessity to ensure adequate durability and limited wear of machine elements significantly influenced the development of various types of coatings used in sliding associations. The name of the DLC (daimond-likecarbon) coating is derived from diamond and carbon [6]. It is a material with mechanical and optical properties similar to diamonds, but it is obtained at a lower cost. Many specialists also use the term amorphous carbon mixed with a diamond with a crystalline structure. Carbon atoms, which form the cubic structure of the diamond, form covalent bonds bonded to each other with the shortest bonds at the highest density of their distribution. This combination makes the diamond have the highest Young's modulus, good thermal conductivity and chemical inertness. Studies have confirmed that the crystallographic orientation of diamond has a significant impact on increasing wear resistance [7]. Coating tests can be performed using a tribotester or FEM [8].

Nanocomposite coatings of the DLC type are thin layers with a thickness measured in micro or nano scale. DLC coatings have a wide range of applications: in the automotive industry (e.g. Common Rail injection systems), industrial production, but also in biomedical applications (e.g. dental implants) $[9,10]$.

Types of DLC coatings, due to their chemical composition [11]:

- a-C - amorphous carbon, devoid of hydrogen, mainly composed of sp2 bonds,

- ta-C - amorphous carbon, free of tetradric bonds, it is the hardest form of DLC coating, having over $80 \%$ of sp3 bonds,

- ta-C: $\mathrm{H}$ - tetrahedral amorphous carbon - hydrogenated,

- $\quad$ a-C: Me - hydrogen-free amorphous carbon with admixtures of elements $\mathrm{W}, \mathrm{Ti}$,

- $\quad \mathrm{a}-\mathrm{C}-\mathrm{H}$ - amorphous hydrogenated carbon; - a-C-H: Me - a nanocomposite coating with admixtures of elements such as: $\mathrm{W}, \mathrm{Ti}$.

- a-C: $\mathrm{H}: \mathrm{X}$ - nanocomposite coating modified with hydrogen and non-metallic elements such as: $\mathrm{Si}, \mathrm{O}$, $\mathrm{N}, \mathrm{F}, \mathrm{B}$.

\section{CONTACT SURFACES COMPENSATING DISC - SATELLITE}

Figure 2 shows a photo taken with the help of a microscope, on which an example of wear of the surface of the compensation disc is visible. Due to the material used for the production of compensation discs - G20 cemented carbide, satellites are subject to excessive wear, in the case of which there is direct contact with the compensation disc. Arrows indicate traces of wear of compensation discs that indicate overheating of the material with noticeable discoloration of the surface layer.

Tribological tests were performed on Tribotester T01M operating in contact pin on disc according to the planned plan of the experiment. The material used was cemented carbide G20 and carbon steel with WC / aC: H coating. Selected D - optimal plan of the

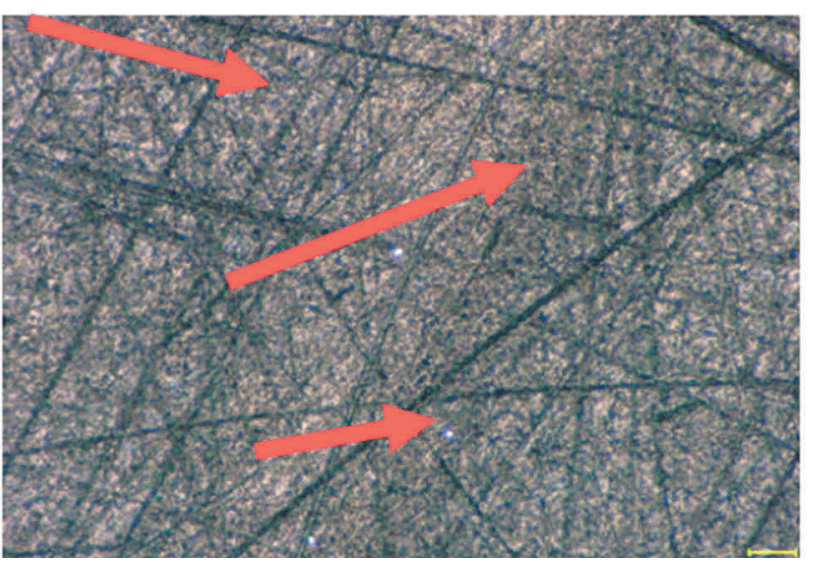

Figure 2 The surface of the compensation disc after cooperation with the satellites - the arrows are marked with scratches on the surface experiment, called the Hartley plan, with three input factors. It required the determination of limit values, for controlled input factors, for which the measurements of the output quantities were carried out. Test time of one sample was 900 seconds. Table 1 presents a combination of some factors in the normed and real scale. 
Table 1 Factors on a normed scale and real scale

\begin{tabular}{|c|c|c|c|c|c|c|}
\hline \multirow{2}{*}{ Sample number } & \multicolumn{3}{|c|}{ Input factors in a normed scale } & \multicolumn{3}{c|}{ Input factors on a real scale } \\
\cline { 2 - 7 } & $\mathrm{x} 1$ & $\mathrm{x} 2$ & $\mathrm{x} 3$ & $\mathrm{~N}, \mathrm{~min}^{-1}$ & $\mathrm{Q}, \mathrm{N}$ & $\mathrm{P},-$ \\
\hline 5 & -1 & 0 & 0 & 200 & 20 & Emulsion \\
\hline 6 & 1 & 0 & 0 & 700 & 20 & Emulsion \\
\hline 7 & 0 & -1 & 0 & 450 & 10 & Emulsion \\
\hline 8 & 0 & 1 & 0 & 450 & 30 & Emulsion \\
\hline 9 & 0 & 0 & -1 & 450 & 20 & Hydraulic oil \\
\hline 10 & 0 & 0 & 1 & 450 & 20 & Water \\
\hline 11 & 0 & 0 & 0 & 450 & 20 & Emulsion \\
\hline
\end{tabular}

During the tribological tests at the T-01M stand, parameters such as blade mass wear $(\mathrm{m})$ and the coefficient of friction $(\mu)$ of the pin on disk association were measured. The measured parameters were used to develop the dependence of mass consumption and the coefficient of friction on controlled - input factors. The results of the research are presented in Figure 3.

\section{0,0006}

n sintered carbide G20 — Carbon steel with WC/a-C:H

0,0005

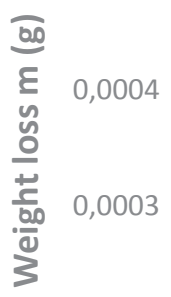

0,0002

0,0001

0,0000

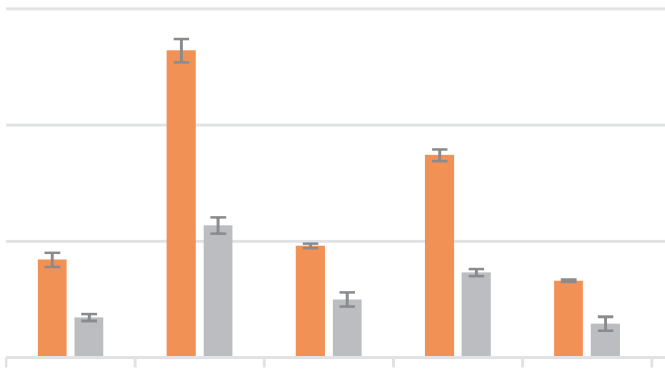

1 2

3

4

$$
5
$$$$
6
$$$$
7
$$

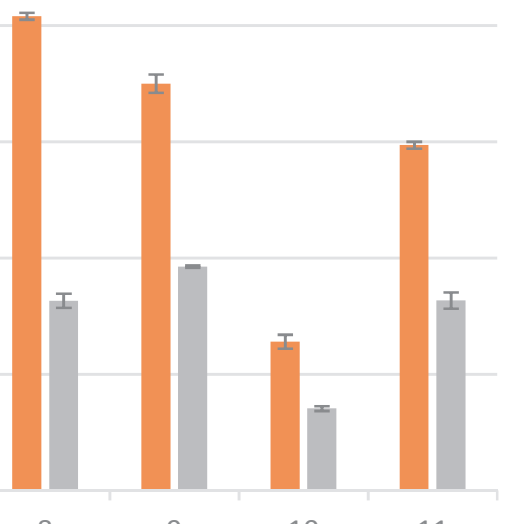

8

9

10

11

Sample number (-)

Figure 3 Mass consumption of the tested compensation disk

The experimental use of $\mathrm{WC} / \mathrm{a}-\mathrm{C}: \mathrm{H}$ coating applied to carbon steel material allowed to reduce mass consumption more than twice, in relation to the currently used material - G20 cemented carbide. On the basis of the D - optimal experiment plan, it was possible to determine the impact of selected operating parameters on sample mass consumption. Samples in order of 5, 11, 6 determine the effect of rotational speed. Samples $7,11,8$ determine the effect of the load. The results in the form of diagrams are shown in Figure 4 and Figure 5.

Analyzing the influence of rotational speed on wear, it was found that with its increase, the wear increases for all tested construction materials. Due to the highest values of mass consumption associated with the increase of the rotational speed, it was found that this parameter is a decisive factor influencing the intensity of wear of the tested combination. 


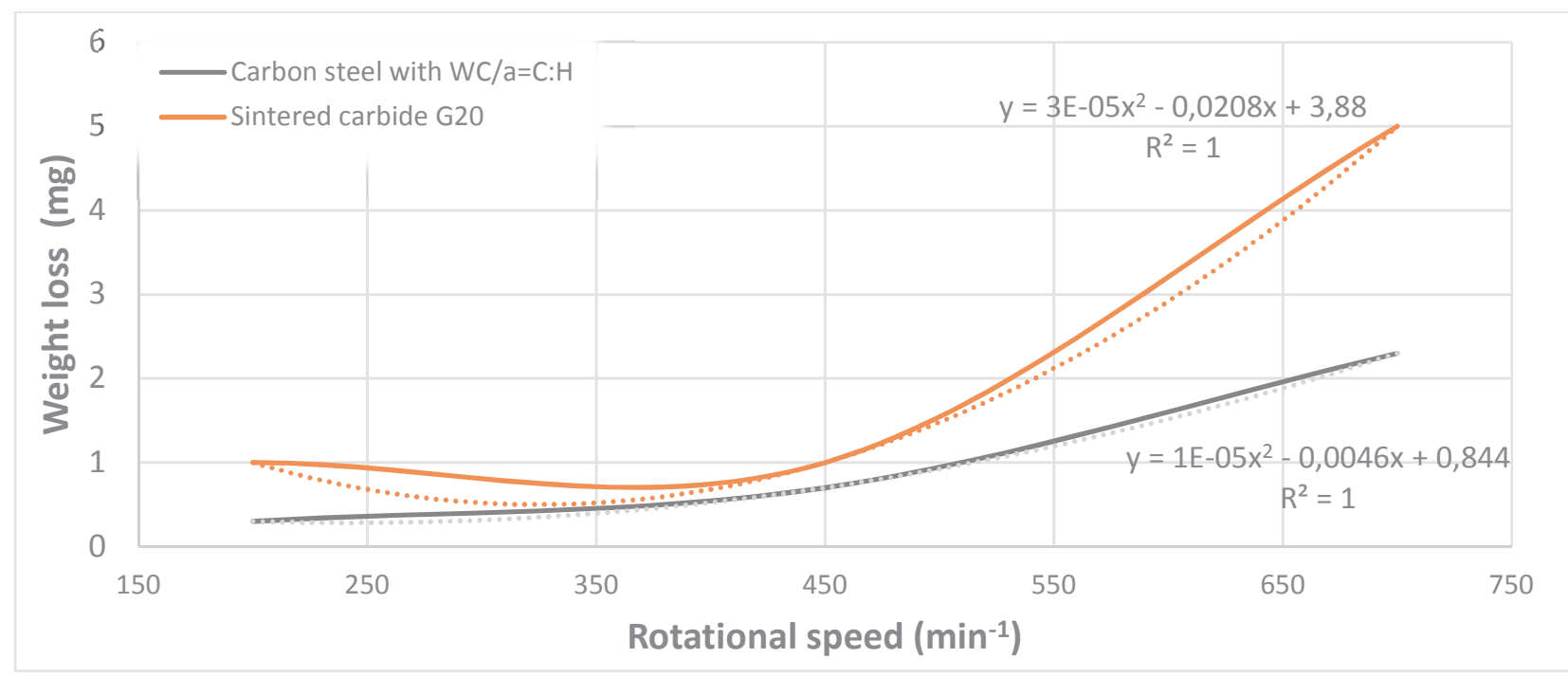

Figure 4 Dependence of wheel weight loss on operating parameters - rotational speed

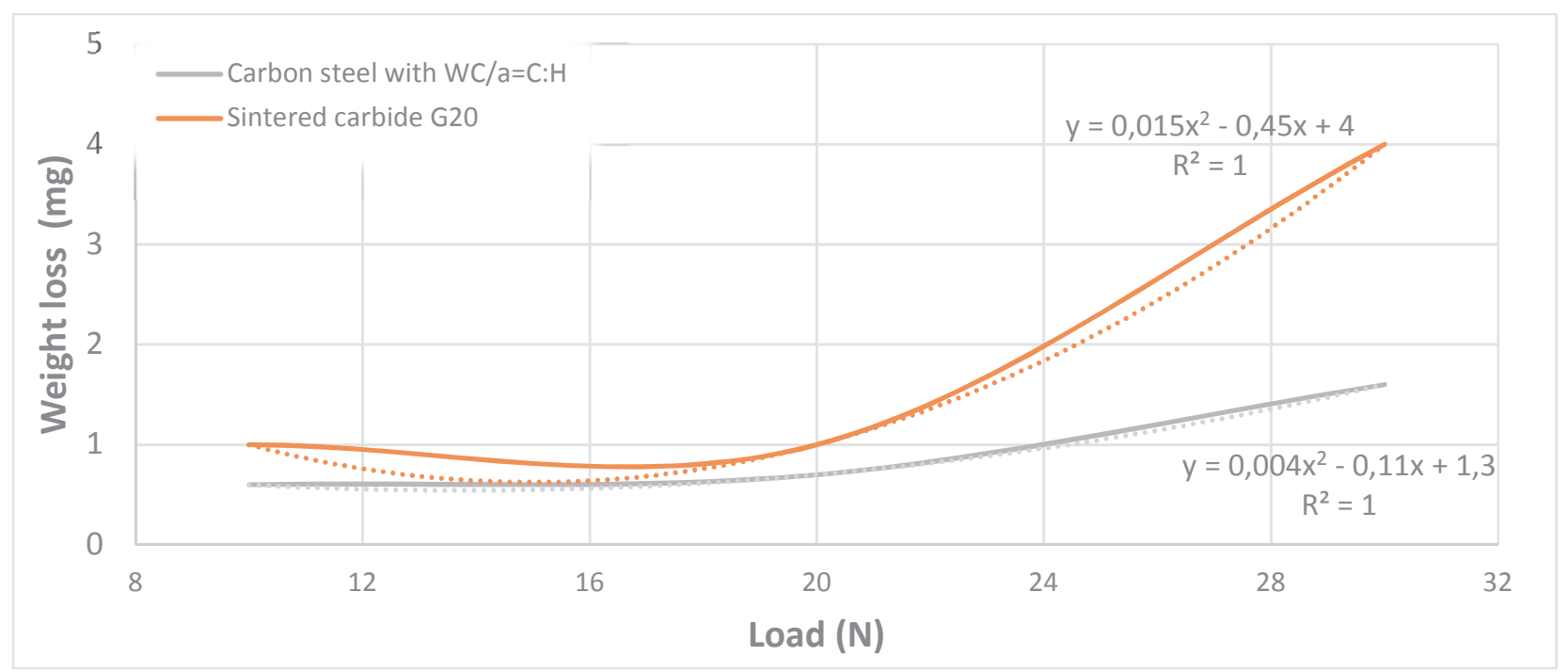

Figure 5 Dependence of wheel weight loss on the load operation parameters

Analyzing the effect of the consumption of material can be seen that the intensity of the cemented carbide material consumption G20 is more twice higher the wear of the coated steel WC / a-C: H.

\section{CONCLUSION}

The research of construction materials and coatings carried out in the work allow for the formulation of the following final conclusions. The scope of tests selected in the work including tribological tests of the surface of the compensation disc is sufficient to determine the influence of operating factors on the properties of the friction combination. The main reason for reducing the durability of hydraulic motors is the working fluid used to power hydraulic motors. Improper filtration systems used in industry, in particular in the coal mining branch, cause solid particles to enter the satellite mechanism. In order to reduce wear and, at the same time, increase the durability of hydraulic motors, it is necessary to use carbon steel and WC / a-C: $\mathrm{H}$ coating, whose tribological properties are the most advantageous of the tested construction materials 


\section{REFERENCES}

[1] JANECKI, Janusz and HEBDA, Michał. Tarcie smarowanie i zużycie części maszyn: Wydawnictwo NaukowoTechniczne, 1969. p. 151.

[2] HEBDA, Michał and WACHA, Andrzej. Trybologia: Wydawnictwo Naukowo-Techniczne, 1980. p. 56.

[3] STANIK, Zbigniew, BĄKOWSKI, Henryk and KUBIK, Andrzej. Analiza zużycia stali bainitycznej w skojarzeniu ślizgowym w wybranych warunkach eksploatacji na stanowisku T-05 (rolka - klocek). TTS Technika Transportu Szynowego. 2016 no. 12. pp. 349-351.

[4] HADRYŚ, Damian. Archives of metallurgy and materials. Mechanical properties of plug welds after micro-jet cooling [online]. 2016. vol. 61. pp.1771-1775. Available from: DOI: https://doi.org/10.1515/amm-2016-0286.

[5] ŚLIWIŃSKI, Paweł. Satelitowe maszyny wyporowe. Podstawy projektowania i analiza strat energetycznych: Wydawnictwo Politechniki Gdańskiej. 2016. p. 166-170.

[6] LIU, Lei, WANG, Tao, HUANG, Jinglin, HE, Zhibing, YI, Yong and DU, Kai, Diamond and Related Material. Diamond-like carbon thin films with high density and low internal stress deposited by coupling DC/RF magnetron sputtering [online]. 2016. vol. 70. pp. 151-158. Available from: DOI: https://doi.org/10.1016/j.diamond.2016.10.004

[7] EL-DASHER, Bassem, GRAY, Jeremy, TRINGEA, Joseph, BIENER, Juergen and HAMZA, Alex. Applied Physics Letters. Crystallographic anisotropy of wear on a polycrystalline diamond surface [online]. 2006. vol. 80. pp. 241915-1-241915-3. Available from: DOI: https://doi.org/10.1063/1.2213180.

[8] BAKOWSKI, Henryk, Archives of metallurgy and materials. Wear mechanism of spheroidal cast iron piston ringaluminum matrix composite cylinder liner contact [online]. 2018. vol. 63. pp. 481-490. Available from: DOI: https://doi.org/10.24425/118965.

[9] JASIOK, Marek. Wpływ naniesienia powłoki dlc na trwałość wybranego elementu układu wtryskowego typu common rail w silniku o zapłonie samoczynnym. Autobusy. 2017. no. 12. pp. 923-927.

[10] OGWU, Abraham and TIT, Okpalugo. Thin Film Coatings for Biomaterials and Biomedical Applications. DLC thin films for implantable medical devices [online]. 2016. pp. 261-287. Available from: DOI:

https://doi.org/10.1016/B978-1-78242-453-6.00011-0.

[11] BEWILOGUA, Klaus, HOFMANN, Detlef, "History of diamond-like carbon films - From first experiments to worldwide applications", Surface \& Coatings Technology, 2014. 